University of Nebraska - Lincoln

DigitalCommons@University of Nebraska - Lincoln

USDA National Wildlife Research Center - Staff Publications
U.S. Department of Agriculture: Animal and Plant Health Inspection Service

2011

\title{
Evaluation of Sonic Dissuader® to Reduce Damage by Pileated Woodpeckers
}

\author{
Shelagh K. Tupper \\ USDA-APHIS, Wildlife Services' National Wildlife Research Center, shelagh.t.deliberto@usda.gov \\ John L. Cummings \\ National Wildlife Research Center, john.I.cummings@aphis.usda.gov \\ William F. Andelt \\ Colorado State University - Fort Collins, william.andelt@colostate.edu \\ Scott Werner \\ United States Department of Agriculture, scott.j.werner@aphis.usda.gov \\ Richard Harness \\ EDM International, Incorporated, rharness@edmlink.com
}

Follow this and additional works at: https://digitalcommons.unl.edu/icwdm_usdanwrc

Tupper, Shelagh K.; Cummings, John L.; Andelt, William F.; Werner, Scott; and Harness, Richard, "Evaluation of Sonic Dissuader® to Reduce Damage by Pileated Woodpeckers" (2011). USDA National Wildlife Research Center - Staff Publications. 1371.

https://digitalcommons.unl.edu/icwdm_usdanwrc/1371

This Article is brought to you for free and open access by the U.S. Department of Agriculture: Animal and Plant Health Inspection Service at DigitalCommons@University of Nebraska - Lincoln. It has been accepted for inclusion in USDA National Wildlife Research Center - Staff Publications by an authorized administrator of DigitalCommons@University of Nebraska - Lincoln. 


\title{
Evaluation of Sonic Dissuader ${ }^{\circledR}$ to Reduce Damage by Pileated Woodpeckers
}

\author{
SHELAGH K. TUPPER, ${ }^{1}$ United States Department of Agriculture, Animal and Plant Health Inspection Service, Wildife Services, National Wildlife \\ Research Center, 4101 LaPorte Avenue, Fort Collins, CO 80521-2154, USA \\ JOHN L. CUMMINGS, United States Department of Agriculture, Animal and Plant Health Inspection Service, Wildlife Services, National Wildlife \\ Research Center, 4101 LaPorte Avenue, Fort Collins, CO 80521-2154, USA \\ WILLIAM F. ANDELT, Department of Fish, Wildlife, and Conservation Biology, Colorado State University, Fort Collins, CO 80523-1474, USA \\ SCOTT J. WERNER, United States Department of Agriculture, Animal and Plant Health Inspection Service, Wildlife Services, National Wildlife \\ Research Center, 4101 LaPorte Avenue, Fort Collins, CO 80521-2154, USA
}

RICHARD E. HARNESS, EDM International, Incorporated, 4001 Automation Way, Fort Collins, CO 80521, USA

\begin{abstract}
Woodpecker damage to utility poles results in significant monetary losses to utility companies worldwide. Most techniques for repelling woodpeckers from utility poles are costly, difficult to install, effective for a limited time, or ineffective. We evaluated the Sonic Dissuader for detecting and deterring pileated woodpecker (Dryocopus pileatus) damage to wooden utility poles in controlled flight pens. The Sonic Dissuader emits pileated woodpecker and avian predator calls contingent upon pecking by woodpeckers. Ratios of departure were lower and woodpeckers spent more time after a pecking event on the pole with the Sonic Dissuader compared to the control pole (paired $t=6.26$, df $=7, P<0.001$, and $F_{1,4}=5.00$, $P=0.089$, respectively). This may substantiate observed behavior of pileated woodpeckers to freeze when confronted with a predator. We did not observe differences in amount of time spent on poles, amount of time spent pecking on poles, and weight of wood chips removed from poles with and without the Sonic Dissuader. We propose that testing distress calls or other repellents as potential deterrents in combination with detection technology is warranted. (c) 2011 The Wildlife Society.
\end{abstract}

KEY WORDS Dryocopus pileatus, predator response, repellent, wildlife damage management.

Pileated woodpeckers (Dryocopus pileatus) are large North American woodpeckers (length 38-51 cm, wt 250-350 g; Bull and Jackson 1995). They occupy mostly deciduous and coniferous forests in southern Canada, and western, midwestern, eastern, and southeastern United States (Bull and Jackson 1995). Their populations have increased 1.5\%/year in the United States from 1966 to 2007 (Sauer et al. 2008).

Pileated woodpeckers cause severe damage to utility poles throughout their range, resulting in significant monetary losses to utility companies. In 1981 and 1982, the Central Missouri Electric Corporation replaced 2,114 poles due to direct and indirect damage by woodpeckers (Stemmerman 1988). Alabama Power Company spent $>$ US $\$ 3$ million in 1 year to replace poles damaged by woodpeckers (Abbey et al. 2000). Estimated cost of replacing poles for Manitoba Hydro in 1992 was US\$9,000/pole (poles, transportation, and installation; Millar 1992). Damage to utility structures has also been reported for Asia (Kuroda 1955, Nakajima and Shimizu 1957, Kazama 1980), Europe (Turcek 1960), and Fennoscandia (Bevanger and Thingstad 1988).

Causes and characteristics of damage by woodpeckers to utility poles vary by species. Ladder-backed woodpeckers

Received: 12 November 2010; Accepted: 16 December 2010

${ }^{1}$ E-mail: shelagh.k.tupper@aphis.usda.gov
(Picoides scalaris) often drill holes on the underside of cross-arms of smaller poles, sometimes boring completely through the cross-arm. Acorn woodpeckers (Melanerpes formicivorus) create large holes for roosting and nesting, and smaller holes for storing acorns. Pileated woodpeckers create distinctive square-shaped holes that initially have an angular cone-shaped appearance inside, typically in the middle to upper portion of the pole below the cross-arm (Dennis 1964).

Stuffed owls, imitation snakes, and similar scare devices have shown little success for deterring woodpeckers (Dennis 1963). Scare devices have been ineffective mostly because of habituation by birds (Rumsey 1970). Protective wraps of solid metal or plastic, and wire and plastic mesh have occasionally reduced damage by woodpeckers, although instances of damage still occur (Stemmerman 1988, Harness and Walters 2005). Numerous chemicals were evaluated for deterring woodpeckers, but none were successful (Jorgensen et al. 1957, Jorgensen 1960). Some chemical repellents have deterred damage by pileated woodpeckers in cage trials at the National Wildlife Research Center (NWRC; J. L. Cummings, United States Department of Agriculture, Animal and Plant Health Inspection Service, unpublished work), but these chemicals have not been evaluated in the field. Disadvantages of many of these techniques include cost, difficulty of installation, longevity 
of the product, and ineffectiveness at deterring woodpeckers (Abbey et al. 2000).

Species-specific sound deterrents typically use vocalizations of the problem species and have been used in control of crows (Corvus brachyrhynchos; Delwiche et al. 2007), house finches (Carpodacus mexicanus), European starlings (Sturnus vulgaris), and American robins (Turdus migratorius; Berge et al. 2007). Vocalizations of the pileated woodpecker include pair-interaction calls for breeding, pair-bond maintenance and courtship, and calls between rivals (Chapman 1939, Humphrey 1946, Kilham 1959, Short 1982). Pileated woodpeckers also utilize nonvocal sounds (e.g., drumming and tapping) for definition of territories and pair communication (Bull and Jackson 1995). Pileated woodpeckers respond to conspecific calls in defense of their territory by drumming, calling, and chasing off intruders (Bull and Jackson 1995). Response to predators typically involves an alarm call, repositioning to gain a better view point, or becoming silent and inconspicuous (Bull and Jackson 1995).

The Sonic Dissuader (Myrica Systems Inc., Winnipeg, Manitoba, Canada) is designed to detect drumming and pecking by woodpeckers and emit pileated woodpecker and avian predator calls. Although this device has shown some promise in field testing (Mcllraith and Berger 2002), a field test in 2005 had inconclusive results due to the timing of installation and associated battery problems. Minor modifications to the battery and on-off switch were made prior to 2007 testing (J. L. Cummings, unpublished work). The objectives of this study were to 1 ) determine the efficacy of the Sonic Dissuader, as designed by Myrica Systems Inc., for detecting and deterring woodpecker damage to utility poles in a controlled environment, and 2) compare the effectiveness of the individual calls of the Sonic Dissuader to deter woodpeckers from utility poles.

\section{STUDY AREA}

We captured pileated woodpeckers $(n=6 \mathrm{M} ; 2 \mathrm{~F})$ from 10 to 19 April 2007 in the Cass Ranger District of Ozark National Forest, Arkansas, USA, using a mist net and recorded pileated calls (York et al. 1998, Tupper et al. 2010). We transported woodpeckers within individual cages $(50 \mathrm{~cm} \times 61 \mathrm{~cm} \times 50 \mathrm{~cm})$ to the NWRC outdoor animal research facility in Fort Collins, Colorado, USA. We pro- vided 1 wooden perch in each transport cage, and food and water ad libitum throughout transport. We held all pileated woodpeckers individually within NWRC's outdoor aviaries $(2.6 \mathrm{~m} \times 2.6 \mathrm{~m} \times 5.3 \mathrm{~m})$. We lined holding pens with nylon-mesh nets to prevent injuries to woodpeckers (Tupper et al. 2010). We tested all woodpeckers individually within a flight pen $(18 \mathrm{~m} \times 36 \mathrm{~m}$ with ht ranging from $2.5 \mathrm{~m}$ to $7.6 \mathrm{~m}$ ). We released all pileated woodpeckers at their capture location upon conclusion of our studies.

\section{METHODS}

We conducted testing on the Sonic Dissuader, as designed by Myrica Systems Inc., from 14 August to 5 October 2007. We fed woodpeckers $20 \mathrm{~g}$ of canned dog food (beef), $35 \mathrm{~g}$ of mealworms, and $50 \mathrm{~g}$ of mixed fruit (apples, oranges, bananas, and grapes) daily (Tupper et al. 2010). While in captivity, each bird was provided free access to $1,1.2-\mathrm{m}$ tall $\times 30$-cm-diameter section of untreated southern yellow pine (Pinus palustris) pole. The capture, care, and use of all subjects were approved by the Animal Care and Use Committees at Colorado State University (study protocol 07-074A-01) and NWRC (protocol QA-1490; S. K. Tupper-Study Director).

Myrica Systems Inc. provided both the Sonic Dissuader and a control device for testing. Each device was housed in a gray utility box that contained electronics for data logging. The Sonic Dissuader was powered by a solar-charged, leadacid gel-cell, and the control device was powered by a $6-\mathrm{V}$ lantern battery. Each unit was designed by Myrica Systems Inc. to detect vibrations from woodpeckers pecking on the pole but exclude vibrations from other sources. When vibrations from woodpeckers were detected, they were logged digitally within the device, along with the temperature, battery power, date, and time of day. The Sonic Dissuader played digital recordings provided by the manufacturer (Table 1) for deterring pileated woodpeckers, whereas the control device did not emit any sounds. The Sonic Dissuader was programmed to broadcast a call when it detected pecking by a woodpecker during daylight hours. The order of calls played was the same for each bird tested. A maximum of 1 call was played within each $15-$ min period per the manufacturer's settings.

Table 1. Response of pileated woodpeckers to woodpecker and predator calls emitted by the Sonic Dissuader at the National Wildlife Research Center, Fort Collins, Colorado, USA, 14 August-5 October 2007. A departure occurred if bird departed the pole within $42 \mathrm{~s}$ of the call being played (twice the length of the longest call).

\begin{tabular}{|c|c|c|c|c|c|c|c|}
\hline Call & $\begin{array}{l}\text { Length of } \\
\text { call (sec) }\end{array}$ & $\begin{array}{c}\text { No. of } \\
\text { broadcasts }\end{array}$ & $\begin{array}{c}\text { No. of } \\
\text { departures }\end{array}$ & $\begin{array}{l}\text { Mean ratio } \\
\text { of departure }\end{array}$ & SE & $\begin{array}{c}\text { Lower } \\
95 \% \text { CI } \\
\end{array}$ & $\begin{array}{c}\text { Upper } \\
95 \% \mathrm{CI} \\
\end{array}$ \\
\hline Pileated woodpecker territorial announcement & 4 & 69 & 22 & 0.35 & 0.10 & 0.124 & 0.580 \\
\hline Pileated woodpecker threat chatter & 16 & 72 & 19 & 0.22 & 0.06 & 0.082 & 0.351 \\
\hline Pileated woodpecker communication chatter & 21 & 67 & 19 & 0.41 & 0.09 & 0.210 & 0.613 \\
\hline Pileated woodpecker drumming & 4 & 69 & 20 & 0.35 & 0.06 & 0.219 & 0.490 \\
\hline Merlin (Falco columbarius) & 5 & 69 & 17 & 0.28 & 0.09 & 0.068 & 0.486 \\
\hline American kestrel (Falco sparverius) & 6 & 68 & 20 & 0.31 & 0.06 & 0.164 & 0.459 \\
\hline Red-tailed hawk (Buteo jamaicensis) & 4 & 72 & 14 & 0.18 & 0.06 & 0.045 & 0.317 \\
\hline
\end{tabular}

${ }^{\text {a }}$ Ratio equals no. of departures divided by total no. of broadcasts averaged across birds. 
Eight woodpeckers, one at a time, were transferred for testing to a flight pen. Within the flight pen, 2, 7.5-m utility poles were installed $26.5 \mathrm{~m}$ apart. Each device was randomly assigned to a pole, mounted $1.5 \mathrm{~m}$ from the top, and placed facing southwest. The Sonic Dissuader was located on the north side of the pen for 4 test birds and on the south side of the pen for the remaining 4 birds. Utility poles were replaced 3 times during the study.

Each bird was released into the flight pen between 0600 hours and 0700 hours on day 1 of testing and remained for a 5-day testing period. The standard diet was placed in the center of the pen and offered daily; water was available ad libitum. The data recorders in the Sonic Dissuader and the control device recorded the 15-min time period during which woodpeckers were detected on the pole and the total number of events (e.g., pecking, weather) recorded for that 15-min period. The Sonic Dissuader also recorded which of the 7 calls was broadcast during the 15 -min period.

Both poles (with and without the Sonic Dissuader) were video-taped (with sound) during daylight hours (05452030 hours). From the tapes, we recorded total amount of time that woodpeckers spent on each pole, the call type emitted by the Sonic Dissuader, the time of the broadcast, and the duration of pecking (sec) before and after the broadcast. Woodchips chiseled off the poles by woodpeckers were collected within a 5-m radius from each pole at the end of each 5-day testing period, placed in a drying oven at $82^{\circ} \mathrm{C}$ for $24 \mathrm{hr}$ to standardize moisture content, and weighed $( \pm 0.1 \mathrm{~g})$.

\section{Statistical Analyses}

We summed the number of times each call was broadcast for each bird each day and the seconds until each bird departed the pole after each broadcast. We considered a departure to occur if the bird left the treated pole within $42 \mathrm{~s}$ (twice the duration of the longest call) after the call was played. In order to standardize departures per number of broadcasts by bird we calculated the ratio of departure from both Sonic Dissuader and control poles. To calculate a ratio of departure we summed the total number of departures among the 7 types of calls and divided by the total number of broadcasts on the treatment pole for each bird. We calculated a ratio of departure from the control pole based on the number of departures within $42 \mathrm{~s}$ after pecking.

To determine the efficacy of the Sonic Dissuader we conducted 5 comparisons between the Sonic Dissuader and control pole. We analyzed time (averaged across days) that pileated woodpeckers occupied and pecked poles with and without the Sonic Dissuader using an analysis of variance (ANOVA [PROC GLM; SAS Institute Inc. 2003]). We analyzed the ratio of departure from the Sonic Dissuader versus control poles with a paired $t$-test (PROC TTEST). We analyzed the mean time to departure from the Sonic Dissuader versus control pole using a repeated-measures ANOVA (PROC GLM). The random effect in our model was bird subjects, the between-subjects effect was treatment, and the within-subject effect was test day. We compared woodpecker damage (i.e., mass of removed wood) on Sonic
Dissuader versus control poles using a paired $t$-test (PROC TTEST).

To compare the effectiveness of the individual calls for deterring pileated woodpeckers we compared the ratio of the number of departures per the total number of broadcasts for each of the 7 calls using an ANOVA (PROC GLM). We used descriptive statistics (mean \pm $\mathrm{SE})$ to summarize departure ratio of birds due to each call.

\section{RESULTS}

The Sonic Dissuader broadcast a call 570 times during the 40 days of testing. Due to a video failure, 63 of the broadcasts from bird 4 were not verified. Of the 570 calls that were broadcast, we verified that 21 calls were caused by weather events (e.g., rain, wind, thunder); the remaining calls were caused by woodpecker pecking. Mean number of broadcasts ranged from 10 to 15 daily and did not vary among the 5 days of testing (Fig. 1).

There was no difference in the amount of time birds spent on poles with Sonic Dissuaders $(\bar{x}=8,217 \mathrm{~s}, \mathrm{SE}=3,576)$ and poles with the control device $(\bar{x}=8,011 \mathrm{~s}, \mathrm{SE}=1,927$; $F_{1,7}=0.00, P=0.962$; Fig. 1). Woodpeckers spent $447 \mathrm{~s}$ $(\mathrm{SE}=148)$ pecking on poles with the Sonic Dissuader compared to $1,744 \mathrm{~s}(\mathrm{SE}=1,043)$ on control poles $\left(F_{1,7}=1.52, P=0.258\right.$; Fig. 1$)$. We detected a smaller ratio of departure from the pole with the Sonic Dissuader $(\bar{x}=0.29, \mathrm{SE}=0.04)$ compared to the control pole $(\bar{x}=$ $0.70, \mathrm{SE}=0.04 ;$ paired $t=6.26, \mathrm{df}=7, \quad P<0.001$; Table 2). After a pecking event, woodpeckers remained on the pole with the Sonic Dissuader longer $(\bar{x}=151 \mathrm{~s}, \mathrm{SE}=$ 20) than control poles $\left(\bar{x}=81 \mathrm{~s}, \mathrm{SE}=9 ; F_{1,4}=5.00\right.$, $P=0.089)$, but time to depart poles did not vary across the 5 days $\left(F_{4,16}=0.21, P=0.928\right)$ nor across the 8 birds $\left(F_{7,4}=0.84, P=0.609\right)$. Woodpecker damage (i.e., mass of removed woodchips) did not differ between poles equipped with the Sonic Dissuader $(\bar{x}=54.7 \mathrm{~g}, \mathrm{SE}=21.3)$ and poles equipped with the control device $(\bar{x}=101.0 \mathrm{~g}, \mathrm{SE}=47.4$; paired $t=0.93, \mathrm{df}=7, P=0.383$; Table 3 ). We did not

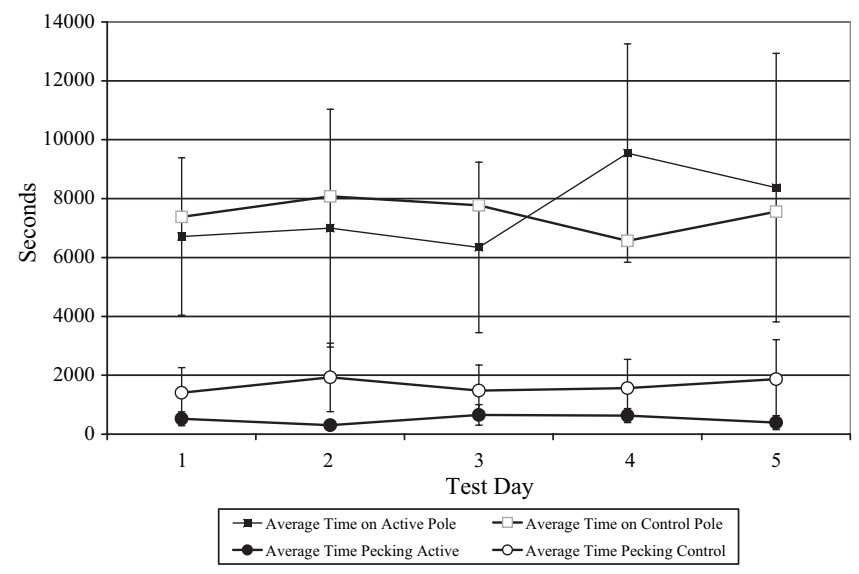

Figure 1. Mean time spent on poles and time spent pecking on poles by pileated woodpeckers $(n=8)$ by day, during testing at the National Wildlife Research Center, Fort Collins, Colorado, USA, conducted 14 August-5 October 2007. Vertical lines represent \pm 1 standard error. 
Table 2. Ratio of departure by pileated woodpeckers from Sonic Dissuader and control poles during testing at the National Wildlife Research Center, Fort Collins, Colorado, USA, 14 August-5 October 2007. A departure occurred if bird departed the pole within $42 \mathrm{~s}$ of the call being played (twice the length of the longest call) or within $42 \mathrm{~s}$ of the last pecking event (control pole).

\begin{tabular}{lccccc}
\hline Treatment & No. of departures & Mean ratio of departure & SE & Lower 95\% CI & Upper 95\% CI \\
\hline Sonic Dissuader & 131 & 0.29 & 0.04 & 0.204 & 0.394 \\
Control & 612 & 0.70 & 0.04 & 0.596 & 0.804 \\
\hline
\end{tabular}

${ }^{\text {a }}$ Ratio equals no. of departures divided by total no. of broadcasts averaged across birds.

detect a difference in ratio of departure among the 7 types of calls from the treated pole $\left(F_{6,49}=1.22, \quad P=0.310\right.$; Table 1).

\section{DISCUSSION}

Woodpeckers typically respond to a raptor attack by jumping to the opposite side of the trunk on which they are feeding, or by adopting a cryptic posture against the tree trunk and "freezing" until danger has abated (Lima 1993). Bull and Jackson (1995) reported that pileated woodpeckers in the wild become silent and inconspicuous or move to the top of the perch without departing when predators are detected. Our findings that pileated woodpeckers remained longer on the pole with the Sonic Dissuader than on the control pole after broadcast of a call suggests they are freezing in response to the call. Although poor video quality precluded identification of specific woodpecker behaviors (e.g., head-cocking), we feel that the difference in departure by pileated woodpeckers was due to a freeze response to perceived danger. Similarly, Sullivan (1984) reported that downy woodpeckers (Picoides pubescens) freeze for several seconds and cease to forage for several minutes upon introduction of red-tailed hawk (Buteo jamaicensis) and sharp-shinned hawk (Accipiter striatus) predator models. Our findings that responses by pileated woodpeckers to various types of calls did not differ was similar to the report by Sullivan (1984) that downy woodpeckers showed no difference in responses to predator models versus alarm calls of group-flocking species.

Most scare devices broadcast calls at predefined intervals (Berge et al. 2007, Delwiche et al. 2007); however, to prevent habituation, scare devices generally need to be relocated periodically (Andelt and Hopper 1996), or supplemented with additional scare tactics (Berge et al. 2007). The Sonic

Table 3. Woodchips removed (g) at completion of 5-day test period by pileated woodpeckers during 40 days of testing at the National Wildlife Research Center, Fort Collins, Colorado, USA, 14 August-5 October 2007.

\begin{tabular}{lccc}
\hline Bird number & Sonic dissuader $(\mathrm{g})$ & Control $(\mathrm{g})$ & Total $(\mathrm{g})$ \\
\hline 1 & 1.1 & 13.8 & 14.9 \\
2 & 42.5 & 21.4 & 63.9 \\
3 & 20.3 & 22.3 & 42.6 \\
4 & 192.5 & 82.9 & 275.4 \\
5 & 69.8 & 25.7 & 95.5 \\
6 & 9.9 & 35.4 & 45.3 \\
7 & 53.8 & 386.5 & 440.3 \\
8 & 47.6 & 219.7 & 267.3 \\
Mean & 54.7 & 101.0 & 155.7 \\
\hline
\end{tabular}

Dissuader is innovative as a damage control technique because it responds only when damage is occurring. However, our test of the Sonic Dissuader failed to detect a significant reduction in the amount of time that pileated woodpeckers spent on poles or in the amount of damage caused by woodpecker pecking. Similar results were found by Harding et al. (2007) in testing the Bird Pro Sound System (Bird-X Inc., Chicago, IL), which also played woodpecker and raptor calls. Although we found no evidence of habituation in our 5-day experiment (Fig. 1), Harding et al. (2007) found that woodpeckers appeared to habituate to the Bird Pro Sound system over mean treatment periods of 30 days.

A number of factors contributed to our inability to detect a difference between the Sonic Dissuader and control pole. The Sonic Dissuader is programmed to broadcast only once within a given 15-min period. Birds do not peck or drum on poles and structures at regular intervals, and some birds may have been deterred early in the $15-\min$ period but returned to cause damage for the remainder of that $15-$ min period without experiencing a negative stimulus.

The Sonic Dissuader is programmed to broadcast 7 different calls from both woodpeckers and 3 predator species. The large variation among birds in their responses may be explained by the fact that birds often respond to calls in different ways. Birds are often drawn into conspecific calls to defend a territory or find a mate (depending on the season), and also to the calls of predators. Taped calls of pileated woodpeckers have been used to lure pileated woodpeckers to mist nets (York et al. 1998, Tupper et al. 2010) and a recorded Eastern screech owl (Otus asio; a potential predator) call has attracted a female pileated woodpecker into an area (Wright 1991).

Despite some of these issues, the Sonic Dissuader was successfully triggered to broadcast a call when woodpeckers drummed or pecked on the pole. Additionally, only $4.0 \%$ of the broadcasts recorded during 40 days of testing were due to events other than triggering by woodpeckers.

\section{MANAGEMENT IMPLICATIONS}

The Sonic Dissuader presents an interesting approach to damage control by responding only when damage is occurring. Devices such as these are innovative in this field. We feel that technology like the Sonic Dissuader has the potential to be the next phase in damage management provided the deterrent portion can be improved upon. We propose that testing distress calls or other repellents as potential deterrents in combination with detection technology is warranted. 


\section{ACKNOWLEDGMENTS}

Our study was funded by Electric Power Research Institute, Palo Alto, California, and New York State Electric and Gas, Binghamton, New York. Mention of companies or commercial products does not imply recommendation or endorsement by the United States Department of Agriculture (USDA). The USDA neither guarantees nor warrants the standard of any product mentioned. Product names are mentioned solely to report factually on available data and to provide specific information. We thank K. Crooks, C. Ghalambor, and several anonymous reviewers for their thoughtful comments on earlier versions of this article. Myrica Systems Inc. provided Sonic Dissuaders and troubleshooting assistance for our study. We also thank the staff of NWRC's Animal Care unit for care of the birds throughout the study.

\section{LITERATURE CITED}

Abbey, M., A. Stewart, and J. Morrell. 2000. Existing strategies for control or remediation of woodpecker damage. Internal Report, Investigation of woodpecker damage prevention methods. Reliant Energy, Houston, Texas, USA.

Andelt, W. F., and S. N. Hopper. 1996. Effectiveness of alarm-distress calls for frightening herons from a fish rearing facility. The Progressive Fish Culturist 58:258-262.

Berge, A., M. Delwiche, W. P. Gorenzel, and T. Salmon. 2007. Bird control in vineyards using alarm and distress calls. American Journal of Enology and Viticulture 58:135-143.

Bevanger, K., and P. G. Thingstad. 1988. The relationship birds-constructions for transmission of electric energy. A survey of present knowledge. Äkoforsk Utredning 1:1-133. (In Norwegian).

Bull, E. L., and J. E. Jackson. 1995. Pileated woodpecker (Dryocopus pileatus). Account 148 in A. Poole, and F. Gill, editors. The birds of North America. The Academy of Natural Sciences, Philadelphia, Pennsylvania, and The American Ornithologists' Union, Washington, D.C., USA.

Chapman, F. M. 1939. Handbook of birds of eastern North America. D. Appleton-Century, New York, New York, USA.

Delwiche, M. J., A. Houk, W. P. Gorenzel, and T. P. Salmon. 2007. Control of crows in almonds by broadcast distress calls. American Society of Agricultural and Biological Engineers 50:675-682.

Dennis, J. V. 1963. Bye-bye pileated. Development and testing of an effective woodpecker repellent. Transmission and Distribution 15:8-10.

Dennis, J. V. 1964. Woodpecker damage to utility poles: with special reference to the role of territory and resonance. Bird-Banding 35:225-253.

Harding, E. G., P. D. Curtis, and S. L. Vehrencamp. 2007. Assessment of management techniques to reduce woodpecker damage to homes. Journal of Wildlife Management 71:2061-2066.

Harness, R. E., and E. L. Walters. 2005. Knock on wood: woodpeckers and utility pole damage. IEEE Industry Applications Magazine 11(2): 68-73.
Humphrey, P. S. 1946. Observations at the nest of a pileated woodpecker. Migrant 17:43-46.

Jorgensen, R. N. 1960. Prevention of woodpecker damage to wooden utility poles. Progress Report No. 1256, Pennsylvania State University, State College, Pennsylvania, USA.

Jorgensen, R. N., H. T. Pfitzenmeyer, and W. C. Bramble. 1957. Prevention of woodpecker damage to wooden utility poles. Progress Report No. 173, Pennsylvania State University, State College, Pennsylvania, USA.

Kazama, T. 1980. Telephone pole breakage caused by green woodpecker Picus awokera. Journal of Yamashina Institute of Ornithology 12:225-226.

Kilham, L. 1959. Behavior and methods of communication of pileated woodpeckers. Condor 61:377-387.

Kuroda, N. 1955. Research and data on woodpecker damage to timber and electric poles. Journal of the Yamashina's Institute of Ornithology and Zoology 30:227-240.

Lima, S. L. 1993. Perspectives on escape from predatory attack: a survey of North American birds. The Wilson Bulletin 105:1-47.

McIlraith, A., and R. Berger. 2002. Prevention of pileated woodpecker (Dryocopus pileatus) damage on Manitoba hydro utility poles. Manitoba Hydro, Winnipeg, Saskatchewan, Canada.

Millar, B. R. 1992. An ecological assessment of the use of hydro utility poles for nesting by pileated woodpeckers in southeastern Manitoba. Thesis, University of Manitoba, Winnipeg, Canada.

Nakajima, S., and K. Shimizu. 1957. Ecological observation of woodpeckers injuring telephone poles and some means of preventing damage. Bulletin of Faculty of Agriculture Miyazaki University 3:12-22.

Rumsey, R. L. 1970. Woodpecker attack on utility poles. Journal of Forest Products 20:54-59.

Institute SAS Inc. 2003. SAS/STAT user's guide. Volume 3. SAS Institute, Cary, North Carolina, USA.

Sauer, J. R., J. E. Hines, and J. Fallon. 2008. The North American breeding bird survey, results and analysis 1966-2007. Version 5.15.2008. U.S. Geological Survey Patuxent Wildlife Research Center, Laurel, Maryland, USA.

Short, L. L. 1982. Woodpeckers of the world. Delaware Museum of Natural History Monograph 4.

Stemmerman, L. A. 1988. Observation of woodpecker damage to electrical distribution line poles in Missouri. Proceedings of the Vertebrate Pest Conference 13:260-265.

Sullivan, K. A. 1984. Information exploitation by downy woodpeckers in mixed-species flocks. Behaviour 91:294-311.

Tupper, S. K., W. F. Andelt, J. L. Cummings, C. Weisner, and R. E. Harness. 2010. Polyurea elastomer protects utility pole crossarms from damage by pileated woodpeckers. Journal of Wildlife Management 74:605-608.

Turcek, F. J. 1960. On the damage by birds to power and communication lines. Bird Study 7:231-236.

Wright, R. 1991. Pileated woodpecker responds to owl tape. The Nebraska Bird Review 59:98-99.

York, D. L., J. E. Davis, Jr., J. L. Cummings, and E. A. Wilson. 1998. Pileated woodpecker capture using a mist net and taped call. North American Bird Bander 23:81-82.

Associate Editor: Stephen DeStefano. 